6. Дудов В. А., Стспанова О. Н. Маркетинг в сіјере физической кутьтуры и спорта: содержание стратегия коммуникапии. - М. : РАГС. 2003.-212 c.

7. Лукашук В. 1. Паб̆лік рілейшнз у спорті // Вісник Харків. нац. ун-ту імені В. Н. Каразіна «Сопіолотіпні дослідження сучасного суспіпетва: методологія, теорія. методи». 2004,- № 621. - C. 109-113.

8. Росса нюк В. С. Экономичсский фактор в спорте // Тсория и практика физнчсской культуры, $-2006,-$ № 1, - C. 21-22.

9. Camy J., Clijsen L., Madella A., Pilkington A. Improving cmployment in the field of sport in Europe through vocational training. - 2004. Vocasport [Елсктронний pecypc]/Pcжим доступу: hitp://curopa.cu.int/comm/sport/documents/loivocasport (21,01.2011).

10. Andreff V., Fentem P., Svoboda B., Vuori L., Weber W. The significance of Sport for Society. - Council of Europe Press, 2005. - 188 p. [Електронний ресурс] // Режим доступу: nww libsport.ru/doc/20fel+a2-4+d5-404+-b626-6802a0cbc83a (2l.01.2011).

11. Самые успешные PR-каппании в мировой практике : пер. с англ. ИНФРА-М.. 2002. - 596 с. [Етектронний ресурс] // Режим доступу: птит.gumer.info/bibliotek_Buks/ Econon/PR/index.php (29.01.2011).

12. Ганиин В. В. Экономика спорта и спортнвный бнзнсс. - М. : КноРус, 2006, $320 \mathrm{c}$.

13. Сго.иров И. Сочинская Олимпнада прсдставляет маркстинговую программу / И. Столяров, - Новости спортивной индустрии. Украина. - К. 2008. - № 3(5), - С. $25-28$.

Hadinuta do pedkoten 05.02 .2013 .

У返 338.48

\title{
T. А. Смирнова
}

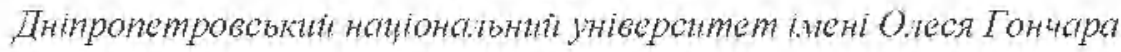

\section{ПЕТРИКІВКА ЯК ЕЛЕМЕНТ БРЕНДУВАННЯ РЕГІОНУ}

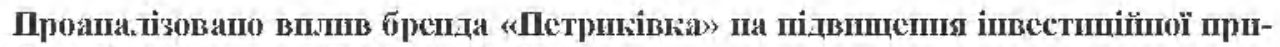

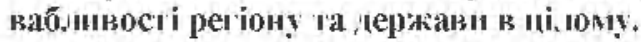

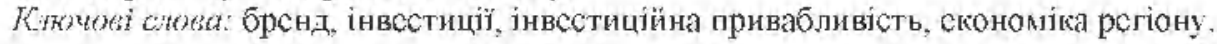

Проана пицровано в.ияние брен, «Пегриковьа» на повышение инвестиционной ирив, лекательноси региона и государства в ие.лоч,

Клочевье стова: бренд. инвестиции, инвестиционная привлекательность. эконоуика ретиона.

Influence of brand «Petrikivka is analysed on the increase of investment attractiveness of region and state on the whole.

Key words: brand, investment, intyestment attraction, the region's cconomy.

Вступ, Минулого року у світі зафіксовано мільярдного туриста. Це показник того, що туризм залишається найпопулярнішим видом відпочинку і масовим соціально-скономічним явищсм міжнародного масштабу. Швидкому його розвитку сприяєе розширсння політичних, скономічних, нау кових і ку льтурних зв" язків між дсржавами і народами світу. Масовий розвиток туризму дозво.лье мільйонам людсй розширити свої знання з історії, знайомитися з пам зтками, культурою та традицімми своєї та інших країн.

3 скономічної точки зору туризм - це додаткові надходжсння до місцсвих бюджжетів. Тому розвиток цього напряму $є$ одним із першочергових завдань влади щодо підвищення інвестиційної привабливості.

С. Т. А. Смирнова, 2013 
Постяновка зявдання. У сучасному світі різні нематеріальні чинники починають всс більше впливати на окономічний розвиток. Найважсивішим напрямом роботи з налагодження міжнародного економічного співробітництва $\mathbf{i}$ за.ту चення јноземних інвестицій е формування позитивното іміджу ретіону і держави,

Свропейсыка практика брендуваняя і побудови іміджу регіону заснована на популяризації унікальних культурно-історичних особтивостей, властивих винятково контретній місцевості і державі.

Дніпропетровщина - центр сучасних знань і високих космінних технологій, один із провідних регіонів Украіни за показниками соціально-скономічного розвитку, зкий має давню славетну історію і самобу тню ку дьтуру. Найбільш упізнанною культурно-історичною пам яткою рсгіону по праву е Пстриківський розпис- - нікальний вид народного дскоративного мистсцтва, відомий у всьому світі. Впродовж стопіть цсй вид мистсцтва живе і розвивається, він $є$ найважливішою складовою іміджу нашого рсгіону зк цснтру унікальної ку льтурноі спадшини України і вејєї Східної Європи.

Петриківський розтис виник у XVIII столітті эк мистецтво прикрашання сільських хат, Завдяки простоті і доступності матеріалів він став справді народним видом мистецтва. А через недовговјчність фарб того часу кожного року орнамент доводилося оновлювати, при цьому роблячии його цікавішим і оритінальніШим โ4].

Це сприяло постійному вдоскона.снню майстсрності художників. Пстриківський розпис псрсжив війни і рсволющіi. У всі часи він симвопізував найважливішу рису національного характсру українців - псревагу духовного над тілссним. фізичним. Алжо навіть у найважчі роки петриківські майстри продовжу вали створювати свої шедеври, які увійшли до скарбниці української культури.

Результати. Популяризація і розвиток Пстриківського розпису - це змінення регіонального і націонатьного патріотизму. Тому керівництво гкрайни починае створювати всі умови для того, щоб знання, унікатьний талант і професіоналізм петриківсыких майстрів передавалися наступним поколінням, Для цього в рамках регіонального проекту в дитячих садках, школах і вузах Дніпропетровщини реалізуються спеціальні тематичні освітні програми, зокрема, щорік у всіх школах проходить єдиний урок Петриківського розпису, а також проводиться масштабний ніжнародний стнофестиваль-sцнарок «Пстриківський дивоцвіт». У Дніпропстровському театрально-ху дожньому колсджа відкрито нову спсціальність - фахівщя з Петриківського розпису.

Пстриківський розпис уже є культурним брсндом Дніпропстровщини і всієі Украйни. Згідно з досліджснням, провсдсним у 2010 році Міністеретвом закордонних справ України в провідних країнах Свросоюзу, європейці асоціюють украйнську культуру саме 3 Петриківським розписом і утраїнською єписанкою\%. Один із цих двох українських кузьтурних іміджевих брендів створений і активно розвивається на Дніпропетровщині, Підтримка і розвиток Петриківки є одним 13 валкливих напрямів затвердження мікнародного іміджу Дніпропетровщини й України у світі як сучасного центру розвитку цього самобутнього мистецтва [4].

За останні роки керівництво Дніпропетровської обтасті зробило серйозні кроки щодо популзгризації Пстриківського розпису не лише в Україні, а й за иї мсжами. У 2012 році розгорну то активну роботу з присвоєння Петриківському розпису статусу нсматсріальної культурної спадшини людства ЮНЕСКО. Цсй статус дозволить розвивати брснд на міжнародному рівні, він означає прийняття розпису світовою спільнотою. Також цс дозволить номінувати Пстриківський розпис на різні гранти і брати унасть у світових просктах.

Головна умова для надання ЮНЕСКО статусу нематеріальної спадщини людства - попу:лянність й історико-культурна цінність елемента нематеріальної спадщини як на йото батьківщині, так ј у світі. Перевага віддається тим явицам $\mathrm{i}$ 
традиціям, які $є$ невід ємною частиною національної культури й одночасно перебувають в постійному розвитку. Петриківський розпис. поза сумнівом. повністю задовольняе всім цим вимогам,

Презеңтація цьото проекту відболася 23 вересня 2012 р. в селищі Петрићјвка за участю надзвичайних і повноважних послів двадцяти крайн світу, а також Координатора просктів ОБСС в Україні. Особливо вразило інозсмних гостей те, що Пстриківським розписом на Дніпропстровщині займаюоться діти, починаючи з трьох-п яти років. Це яскравс підтвсрдження того, що Петриківський розпис справжне наро,днс мистсцтво Ґ1ך.

Можна псредбачити, шо визнання аПстриківки» всссвітньою культурною спадщиною викличе приплив у ретіон іноземних туристів, зміцнення міжнародних зв язків та іміджу Дніпропетровщини й України як центру унікальної самобутньої культури. Чемпіонат Європи з футбол, успішно проведений в Україні торік, відкрив нашу країну для Свропи і світу. Необхідно розвивати цей устік. Дніпропетровщина володіє значним туриетичним потенціялом, і його необхідно максимазьно ефективно використовувати, А перлиною будь-якото туристичното маршруту по рсгіону повинна стати Пстриківка.

Цього року плануетьсл організдція виставок Пстриківеького розпису у всік провідних країнах Свропи. Дльг того, щоб зробити Пстриківку максимально впізнанною і створити у свідомості житспів інших дсржав стійкий зв ззок між циц унікальним культурним зывищем і Україною, сьогодні вже розроб̆лсно і прсзснтовано новий брснд Пстриківки. Цсй символ у конснтрованому виг.льді вілображає всі особ.ливості Петриківсыкого розпису, він однозначно впізнанний і прекрасно тицить для розміщення на будь-якій продукції.

У примпенні Свропарламенту в Брюссель відбулися стухання з питань регіонального розвитку і презентація інвестиційното потенціату Дніпропетровської області, утраїнсықа делетація представила виставку Петриківсыкого розтису.

Важливість цієї події для зміцнення стосунків між Україною і Євросоюзом відзначили провідні европсйські політики, присутні на відкритті.

Так. Європсйський комісар з питань розширсння і політики добросусідства Штефан Фюлс назвав провсдсння виставки Потриківського розпису в Європарламснті кроком до поглиб..снни взаємин між Свросоюзом і У країною.

Мені пощастило кілька років тому відвідати Дніпропстровеький рсгіон. Дуже радий, що можу бути присутнім тут, у Свропсйському Парламснті, на відкритті виставти Петриківського розпнсу. Це важлива виставка. Чому л так вважаю" У наших відносинах міхк Свросоюзом і Утраӥною ми працюемо в татегоріях політичних декларацій ј мені здається, що в цих важливих стосунках вјдсутня особа, відсутня душа... Ця виставка робить той малий крок до того, щоб усі ми, хто працює над пог.тибленням наших відносин між Євросоюзом і Україною, не забували, що ми робимо це від імені всіх українських людей, що живуть в Свросоюзі. А ци виставка і ці красиві картини нам у цьому дужс допомагають. Великс спасибі за цю ініціативу», - сказав Штсфан Фюлс на вілкритті виставки унікального явища українського мистецтва - Пстриківського розпису [2].

На виставці було прсдставлено понад 90 кращих робіт народних майстрів Дніпропстровської об.ласті - розписані панно, посуд, іграшки, писанки. Нсзаб̆аром у Бс.ьгї відбу дуться щс двї виставки Пстриківського розпису, потім три подібні будуть організовані у Франції, в тому числі у штаб-квартирі ЮНЕСКО.

Найближчим часом такок планується створити робочу гртпу, яка займеться розробкою інших туристичних маршрутів, підготовкою англомовних екскурсоводів та поліпшенням умов проякивання д.я туристів.

У перспективі також розробка цілого ряду регіональних маршрутів, які дозволять гостям відкрити для себе Дніпропетровщину. Серед них:

- Дніпропстровськ - ракстно-космічна сто.ищя України: 
- Петриківсыкі орнаменти:

- історія українського козацтва:

- правостав я Дніпропетровщини:

- скіфо-сарматська јеторія Придніпров я:

- промисловий туризм:

- «зслсний» туризм [1].

Висновки. Сучасний проскт популяризації Пстриківського розпису як духовного і ку .ьту рного орснда рсгіону в країнах Європи і світу - важлива складова інтсграції Дніпропстровщини й України в міжнародний простір.

У рамках ініціативи України зараз розглядається питання про присвоєння Петриківсыкому розпису статусу нематеріальної культурної спадщини .юдства ЮНЕСКО. Відповідне досье номінації було підтотовлене в червні 2012 року Міністерством закордонних справ і Міністерством культури України.

Досвід найуспішніших світових корпорацій свідчить, що активне використання яскравого і самобутнього бренда сприяе значному зростанню інтересу пожупців. А у сучасному світі қультура, витвори мистецтва - це важливий товар. Не слід болтиск комсрціалізації такого споконвічно народного промислу зк Пстриківський розпис.

Увага інозсмних інвссторів дозволить створити нові робочі місцз, вивести Пстриківку на новий, міжнародний рівснь, а в перспективі створити псредумови д.ль широкої ку.льтурної скспансії України.

Слід вілзначити, що зусилля із формування позитивного іміджу облласті й України вже приносять свої плоди. Завдяки успішній роботі з міжнародними бізнес-колами, Дніпропетровщина упевнено лідируе в Україні за обсятами прямих іноземних інвестицій. Передовий досвід нашого регіону обов'язково буде використаний для підвищення іңвестиційної привабливості всієї країни. А Петрижјвський розпис, як найвідоміший за межами держави культурний символ України, повинен стати для іноземців провідником у світ високої культури українського народу.

\section{Бібліографімні посилання}

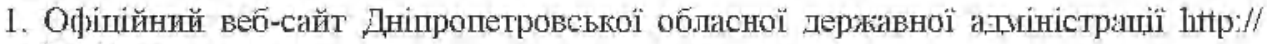
www.adin.dp. иа

2. Офіційний веб-сайт Дніпропетровсыкої обласної ради litp://www, oblrada,dp, ua

3. Офріційний Тнтсрнет-портал Дніпропстровської хгісыкоі радиhlip://niprorada.

4. Путсводитсль по Днепропетровщинс-информацня о Днспропетровской области litip//www lourdncpr.com

Hadiùuta do peokomerï 09.02.2013.

удК $339.9: 336.1$

М. В. Литвин

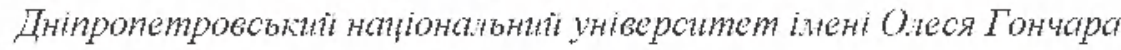

$$
\begin{gathered}
\text { ФІНАНСУВАННЯ РЕГІОНАЛЬНОГО РОЗВИТКУ ІСПАНІЇ } \\
\text { В КОНТЕКСТІ ДОСЯГНЕННЯ СТАЛОГО РОЗВИТКУ }
\end{gathered}
$$

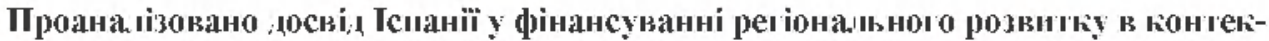
спі забезиечення сталого розвиту. Визначено қжере. фа фінансування економічного

С. М. В. Литвин, 2013 